\title{
EFFECT OF HOT-WATER TREATMENT AND BULB STORAGE TEMPERATURE ON PROPAGATION OF NARCISSUS TAZETTA BY THE CHIPPING AND TWIN-SCALING TECHNIQUES
}

\author{
Khalafalla, M. M. ${ }^{1}$ - Eltarawy, M. ${ }^{1}-$ SAAD, M. E. A. ${ }^{2}-$ Hegazy, A. ${ }^{*}$ \\ ${ }^{1}$ Hort. Dept., Fac. Agric., Kafrelsheikh Univ., Kafrelsheikh 33516, Egypt \\ ${ }^{2}$ Hort. Res. Inst., Agric. Res. Center, Giza, Egypt \\ *Corresponding author \\ e-mail:ahmed.ebad@rocketmail.com
}

(Received $26^{\text {th }}$ Feb 2019; accepted 24 ${ }^{\text {th }}$ May 2019)

\begin{abstract}
In the current study there were 6 treatment of all combinations of two propagation methods (chipping and twin-scaling), two propagating bulb storage temperatures (pre-cooling and no pre-cooling), two hot-water treatments (hwt and no hwt). Treatments were applied to measure the effects on the propagation of Narcissus tazetta cv. "Ziva" bulbs. The major effects were those of propagation methods and pre-propagating bulb storage temperatures. Chipping, pre-cooling and hwt consistently affected the bulblet formation in both seasons and bulblet weight per chip in the first season only but had no effect on number of bulblets. Chipping method increased all parameters (bulblet formation, weight and circumference of bulblet and number of bulblets per chip, number and length of leaves and roots per-chip). However, chipping resulted in lager, but fewer bulblets than twin-scaling. Pre-cooling increased bulblet formation and both weight and circumference of bulblet in the first season only but reduced number and length of leaves and roots in the second one only. Hot-water treatment increased bulblet formation in both seasons but reduced number and length of leaves and roots in the first season only.
\end{abstract}

Keywords: Narcissus, chipping, twin-scaling, bulblet, hot-water treatments, bulb storage temperature

\section{Introduction}

Narcissus, a genus of the Amaryllidaceae family, consisting of about 62 species, classified into 12 sections (Kington1989). These bulbs are well known garden perennial, cut flowers, and can also be used as flowering potted plant. In addition to its horticultural values, the genus Narcissus provides numerous alkaloids, some of which exhibit pharmaceutical importance (Bastida et al., 2011). The natural vegetative propagation rate of narcissus under field conditions is very slow, with the mother bulb produce few daughter bulbs, approximately 1.6 bulbs per year (Rees, 1972, 1992). In vitro propagation through tissue culture has been successfully used for narcissus (Malik and Bach, 2017). However, compared to chipping and twin-scaling, in vitro propagation is costly. Chipping and twin-scaling are two of conventional propagation techniques for rapidly propagating narcissus bulbs, enabling an increase from 1 to 1000 in 5-6.5 years instead of 15-25 years (Hanks, 1993). In chipping, bulbs are divided into 8 or 16 longitudinal segments depending on bulb size, but these are not subdivided further (Andrade-Rodringuez et al., 2015; Kharrazi et al., 2107), while in twin-scaling are further divided by removing scale pieces in pairs by cutting through the attached basal plate. In this technique bulb is cut into 50 to 100 twin-scales, depending on its size (Hanks, 1993; Zahng et al., 2013). Pretreatment of bulbs may profoundly affect the bulblets production from chipping and twin-scaling. Studies found in literature have reported the successful use of hot-water treatment before narcissus bulb cutting to increase bulblet yields, and control bulb mite 
(Hanks, 1993). However, bulb storage temperature, has been reported to increase (0-10 weeks at $5-30{ }^{\circ} \mathrm{C}$; Hanks et al., 1986) or decrease $\left(5\right.$ days at $35^{\circ} \mathrm{C}$; Rees and Hanks, 1984 ) bulblets production, to be without effect (5 weeks $9{ }^{\circ} \mathrm{C}$; Hanks and Rees, 1978). This study aimed to investigate chipping and twin-scaling techniques and to determine the effect of bulb storage temperature and hot-water treatment on propagation of Narcissus tazetta to achieve a high yield of bulblets.

\section{Materials and methods}

Bulbs of paperwhite Narcissus tazetta cv. "Ziva" were obtained from a commercial source Sperli- GmbH. In an experiment there were 8 treatments, consisting of all combinations of two hot water treatments (hwt and non-hwt) two pre-cutting storage temperatures (pre-cooled and non-pre-cooled bulbs) and two methods for propagation (chipping and twin-scaling). On July $1^{\text {st }}, 2014 / 2015$ and 2015/2016 bulb were graded, single-nosed, round bulbs $12-14 \mathrm{~cm}$ in circumference were selected, cleaned and divided into two groups of 48 bulbs each. In the first group the bulbs were given a hot water treatment (hwt) at $43.5^{\circ} \mathrm{C}$ for $3 \mathrm{~h}$, with $1.5 \%(\mathrm{v} / \mathrm{v})$ formalin, while in the second one they were soaked in a tap-water with $1.5 \%$ (v/v) formalin (non-hwt). After drying, the bulbs were stored at ambient temperature ( $27 \pm 3$ and $20 \pm 3{ }^{\circ} \mathrm{C}$ day/night, $\left.\mathrm{RH} 67-70 \%\right)$ until 6 weeks, prior to bulbs cutting time. Both groups were further divided into two subgroups of 24 bulbs each, the first subgroup was moved to a controlled chamber at a constant temperature of $9{ }^{\circ} \mathrm{C}, \mathrm{RH} 65-70 \%$ (pre-cooled bulbs), while the second one was left in the same ambient temperature (non-cooled bulbs) as described above until the start of the bulbs cutting treatments. On October $3^{\text {rd }}$ in both seasons, half of the bulbs of each group were propagated by chipping technique, while the other half was propagated by twinscaling. Finally, each experiment included 12 bulbs ( 3 replication $\times 4$ bulbs).

\section{Methods of bulb cutting}

After removing the outer brown tunicated scales, and outer crust of basel plate, the top of bulbs was cut off for about $2.5 \mathrm{~cm}$. For chipping, bulbs were longitudinally cut into eight equal sized segments. For twin-scale cuttings, segments of each bulb were divided into pairs of scales (twin-scales) by cutting through the basal plate, however the outer papery scales and the very small ones were discarded (stored to reject any outside the range 0.8-1.0 g) hence each segment gave about 4 twin-scales (Hanks, 1985). Both chips and twin-scales were dipped in a fungicide solution with $1 \%$ captan plus $0.4 \%$ benomyl (benlate) for $30 \mathrm{~min}$. After dipping and draining, either 12 chips or 16 twin-scales were placed in thin polyethylene bags $(20 \times 30 \mathrm{~cm})$ filled with $500 \mathrm{ml}$ sterile vermiculite previously mixed with $40 \mathrm{ml}$ sterile distilled water and sealed by ensuring air space at top. The bags were incubated in single layer in the dark at $20-22{ }^{\circ} \mathrm{C}$ and relative humidity of $70-80 \%$. After 15 weeks of incubation, the bulblet formation calculated as the percentage of chips and twin-scales with visible bulblet, number of bulblets per chip and twin-scale, number and length (the longest, $\mathrm{cm}$ ) of leaves and roots and circumference $(\mathrm{cm})$ and weight $(\mathrm{g})$ of each bulblet were determined. The experimental design was factorial in a complete randomized with three replicates. The data were subjected to statistical analysis and means were compared according to Duncan's multiple range test (Snedecor and Cochran, 1980).

The following is an explanation of the shape of the cutting methods used: 


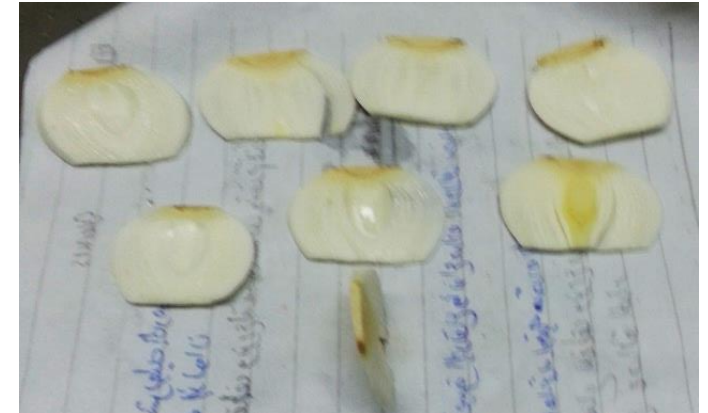

Chipping

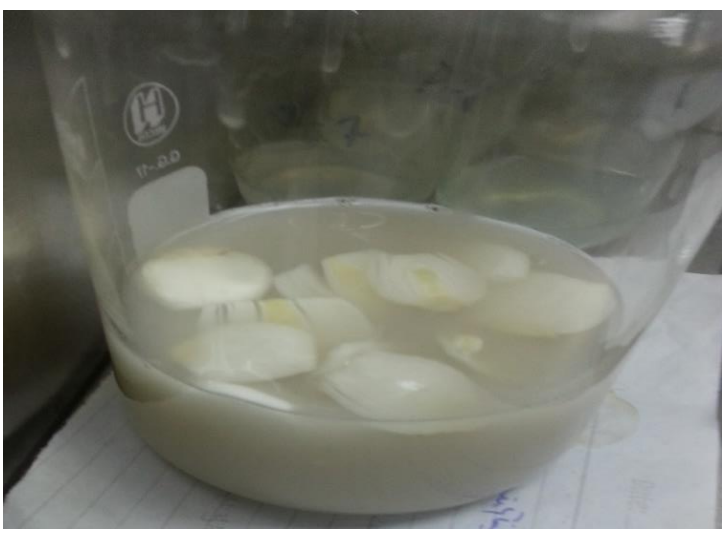

Chips and twin-scales were dipped in a fungicide solution with $1 \%$ captan $+0.4 \%$ benomyl (benlate) for $30 \mathrm{~min}$
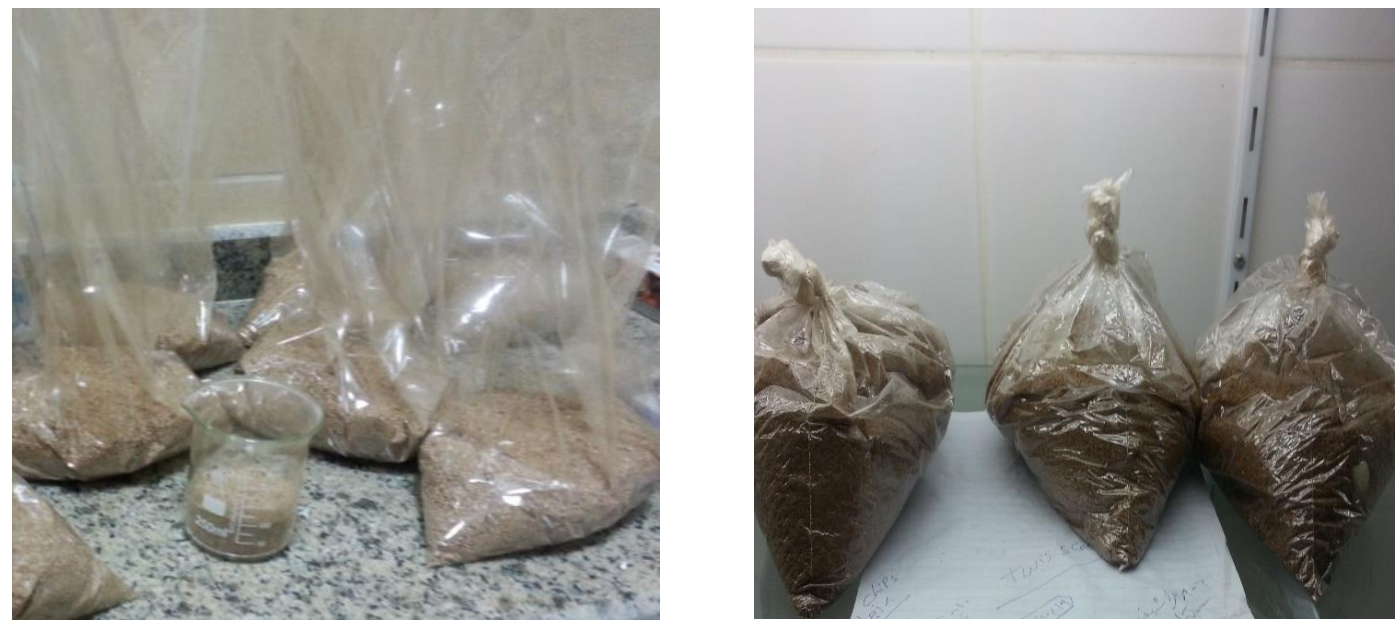

Thin polyethylene bags $(20 \times 30 \mathrm{~cm})$ filled with $500 \mathrm{ml}$ sterile vermiculite previously mixed with $40 \mathrm{ml}$ sterile distilled water and sealed by ensuring air space at top

\section{Results}

\section{Bulblet formation}

Data presented in Table 1 reveal that there were significant effect of propagation methods (chipping or twin-scaling), pre-propagating storage temperature (pre-cooled or non-pre-cooled bulbs) and hot-water treatment (bulb given hot-water treatment (hwt) or non hwt) on the percentage of bulblet formation. In comparison with the alternative treatments, chipping, pre-cooling, hwt increased bulblet formation in both seasons. The interaction between cutting methods, bulb storage temperature and hwt also 
significantly affected bulblet formation in the second season only (Fig. 1). In this interaction, the bulblet formation of the chips was in $100 \%$ irrespective of the prepropagating storage temperature or whether not hot-water treatment was performed. In twin-scales, the highest bulblet formation (96.67\%) was obtained in bulbs given precooling, hwt.

Table 1. The effects of cutting methods (C.M), hot-water treatments (hwt), bulb storage temperature (S), and their combination on bulblet formation (\%), circumference (cm) and fresh weight $(F W)$ of bulblet $(g)$, number of bulblets per propagules (No.), number and length $(L, \mathrm{~cm})$ of leaves and roots in the first and second seasons

\begin{tabular}{|c|c|c|c|c|c|c|c|c|c|c|c|c|c|c|c|c|}
\hline \multirow{2}{*}{ Season } & \multicolumn{2}{|c|}{ Bulblet form. } & \multicolumn{2}{|c|}{ Bulblet fw } & \multicolumn{2}{|c|}{ Bulblet circ. } & \multicolumn{2}{|c|}{ No. bulblets } & \multicolumn{2}{|c|}{\begin{tabular}{|l|} 
No. leaves \\
\end{tabular}} & \multicolumn{2}{|c|}{ L. leaves } & \multicolumn{2}{|c|}{ No. roots } & \multicolumn{2}{|c|}{ L. roots } \\
\hline & $\mathbf{1}^{\text {st }}$ & $2^{\text {nd }}$ & $1^{\text {st }}$ & $2^{\text {nd }}$ & $1^{\text {st }}$ & $2^{\text {nd }}$ & $1^{\text {st }}$ & $2^{\text {nd }}$ & $1^{\text {st }}$ & $2^{\text {nd }}$ & $1^{\text {st }}$ & $2^{\text {nd }}$ & $1^{\text {st }}$ & $2^{\text {nd }}$ & $1^{\text {st }}$ & $2^{\text {nd }}$ \\
\hline Cutting methods & & & & & & & & & & & & & & & & \\
\hline Chipping & $86.68 \mathrm{a}$ & $100.00 \mathrm{a}$ & $0.34 \mathrm{a}$ & $0.35 \mathrm{a}$ & $2.58 \mathrm{a}$ & $2.29 \mathrm{a}$ & $1.50 \mathrm{a}$ & $1.42 \mathrm{a}$ & $2.09 \mathrm{a}$ & $1.62 \mathrm{a}$ & $2.31 \mathrm{a}$ & $2.01 \mathrm{a}$ & $2.34 \mathrm{a}$ & $1.80 \mathrm{a}$ & $2.65 a$ & $1.84 \mathrm{a}$ \\
\hline Twin-scaling & $76.86 \mathrm{~b}$ & $86.25 \mathrm{~b}$ & $0.17 \mathrm{~b}$ & $0.25 \mathrm{~b}$ & $2.04 \mathrm{~b}$ & $1.89 \mathrm{~b}$ & $1.34 \mathrm{~b}$ & $1.00 \mathrm{~b}$ & $1.63 \mathrm{~b}$ & $1.49 \mathrm{~b}$ & $1.59 \mathrm{~b}$ & $1.80 \mathrm{~b}$ & $1.58 \mathrm{~b}$ & $1.53 \mathrm{~b}$ & $1.84 \mathrm{~b}$ & $1.38 \mathrm{~b}$ \\
\hline $\begin{array}{l}\text { Hot-water } \\
\text { treatment }\end{array}$ & & & & & & & & & & & & & & & & \\
\hline Non-hwt & $78.49 \mathrm{~b}$ & $92.01 \mathrm{~b}$ & 0.26 & 0.31 & 2.30 & 2.20 & 1.50 & 1.25 & $1.99 \mathrm{a}$ & 1.50 & $2.07 \mathrm{a}$ & 2.04 & $2.06 \mathrm{a}$ & 1.63 & $2.47 \mathrm{a}$ & 1.55 \\
\hline Hwt & $85.05 \mathrm{a}$ & $94.08 \mathrm{a}$ & 0.25 & 0.29 & 2.31 & 1.98 & 1.34 & 1.17 & $1.73 \mathrm{~b}$ & 1.61 & $1.84 \mathrm{~b}$ & 1.78 & $1.85 \mathrm{~b}$ & 1.70 & $2.02 \mathrm{~b}$ & 1.67 \\
\hline $\begin{array}{c}\text { Bulb storage } \\
\text { temp. }\end{array}$ & & & & & & & & & & & & & & & & \\
\hline Non-pre-cooling & $79.03 b$ & $89.50 \mathrm{~b}$ & $0.23 \mathrm{~b}$ & 0.31 & $2.22 \mathrm{~b}$ & 2.07 & 1.34 & 1.25 & 1.84 & $1.68 \mathrm{a}$ & 1.95 & $2.16 \mathrm{a}$ & 2.07 & $1.74 \mathrm{a}$ & 2.35 & $1.78 \mathrm{a}$ \\
\hline Pre-cooling & $84.51 \mathrm{a}$ & $96.59 \mathrm{a}$ & $0.28 \mathrm{a}$ & 0.26 & $2.39 \mathrm{a}$ & 2.11 & 1.50 & 1.17 & 1.88 & $1.44 \mathrm{~b}$ & 1.96 & $1.65 \mathrm{~b}$ & 1.84 & $1.59 \mathrm{~b}$ & 2.14 & $1.44 \mathrm{~b}$ \\
\hline Significances & & & & & & & & & & & & & & & & \\
\hline C.M & $*$ & $*$ & $*$ & $*$ & $*$ & $*$ & $*$ & $*$ & $*$ & $*$ & $*$ & $*$ & $*$ & $*$ & $*$ & $*$ \\
\hline Hwt & $*$ & $*$ & $\mathrm{~ns}$ & ns & $\mathrm{ns}$ & ns & $\mathrm{ns}$ & ns & $*$ & ns & $*$ & $\mathrm{~ns}$ & $*$ & ns & $*$ & ns \\
\hline $\mathrm{S}$ & $*$ & $*$ & $*$ & ns & $*$ & ns & ns & ns & ns & $*$ & ns & $*$ & ns & $*$ & ns & $*$ \\
\hline C.M $\times$ hwt & ns & $*$ & ns & ns & $*$ & ns & $\mathrm{ns}$ & ns & ns & ns & ns & ns & ns & ns & $*$ & ns \\
\hline $\mathrm{C} . \mathrm{M} \times \mathrm{S}$ & ns & $*$ & $*$ & ns & $*$ & ns & ns & ns & ns & ns & ns & $*$ & ns & ns & $\mathrm{ns}$ & ns \\
\hline Hwt $\times \mathrm{S}$ & $*$ & $*$ & $\mathrm{~ns}$ & ns & $\mathrm{ns}$ & ns & $\mathrm{ns}$ & ns & $*$ & ns & ns & ns & $\mathrm{ns}$ & ns & $*$ & ns \\
\hline C.M $\times$ hwt $\times$ S & ns & $*$ & $*$ & ns & $\mathrm{ns}$ & ns & $\mathrm{ns}$ & ns & $\mathrm{ns}$ & ns & ns & ns & $\mathrm{ns}$ & ns & ns & ns \\
\hline
\end{tabular}

Main effect followed by different letters with in a column are significantly different at $P<0.05$, Duncan's multiple range test ns: not significant; *significant at $P<0.05,1^{\text {st }}$ first season; $2^{\text {nd }}$ second season; Temp.: temperature; form.: formation; circ.: circumference

\section{The fresh weight, circumference and number of bulblets:}

Chipping method significantly increased fresh weight, circumference and number of bulblets in both seasons Table 1, while pre-cooling increased both fresh weight and circumference of bulblet in the first season only. However, hot-water treatment had no effect. In the first season the interaction revealed that, chipping method, pre-cooled bulbs produced a heavier maximum weight and circumference of bulblet than twinscaling method, non-cooled bulbs (Figs. 2 and 3). However, chipping method, hwt produced a wider maximum circumference of bulblet than twin-scaling, hwt. There were also significant effects of cutting method, pre-propagating storage temperature and hwt on fresh weight of bulblet in the first season (Fig. 2). Chipping, pre-cooling and hwt produced bulblets that were heavier than those of twin-scaling, pre-cooling and hwt. There were non-significant effects of pre-cooling, hwt and all combinations on bulblet numbers per both chip and twin-scale in both seasons. 


$$
-10297 \text { - }
$$

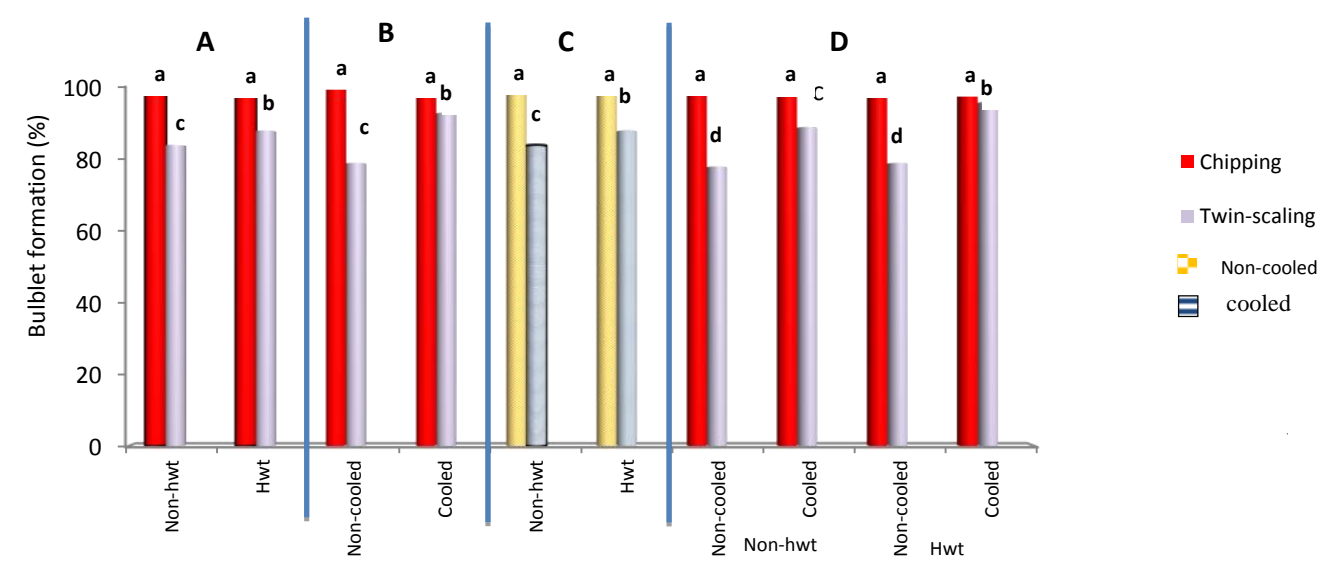

Figure 1. Effect of cutting methods (chipping; twin-scaling) and hot water treatments (hwt; non-hwt) (A), cutting methods and bulb storage temperatures (cooled; non-cooled) (B), hot water treatments and bulb storage temperatures $(C)$, and cutting methods and hot water treatments, bulb storage temperatures $(D)$ on bulblet formation $(\%)$ in the second season. Columns with different letters are significantly different at 0.05 level based on Duncan's multiple range test

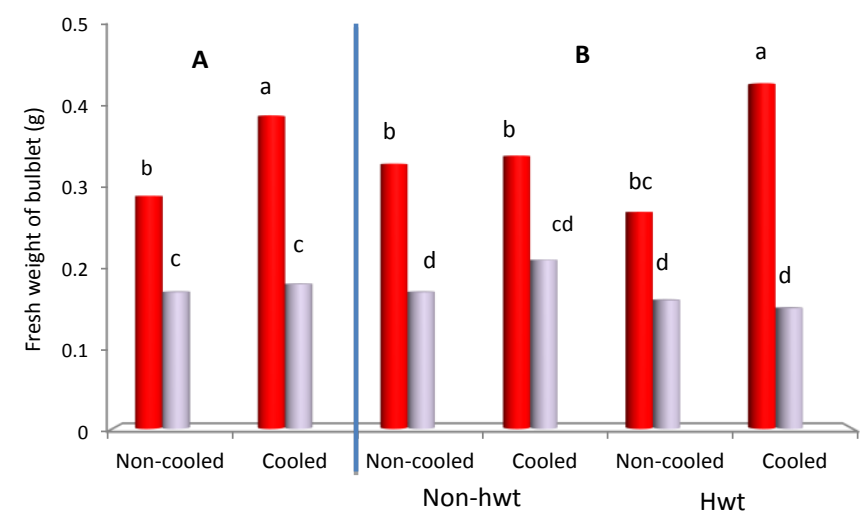

Figure 2. Effect of cutting methods and bulb storage temperature (A), and cutting methods, hot water treatments and bulb storage temperatures $(B)$ on fresh weight of bulblet $(g)$ in the first season (other details are as in Fig. 1)

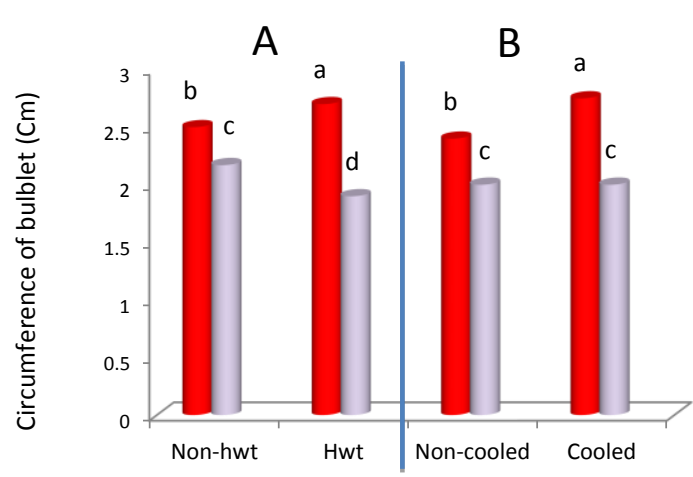

Figure 3. Effect of cutting methods and hot water treatments (A) and cutting methods and bulb storage temperatures $(B)$ on circumference of bulblet $(\mathrm{cm})$ in the first season (other details are as in Fig. 1) 


\section{Number and length of leaves and roots per bulblet:}

Data presented in Table 1 show that, chipping method significantly increased number and length of leaves and roots in both seasons, while pre-cooling treatment in the second season and hwt in the first one significantly decreased both number and length of leaves and roots. However, the interaction revealed that pre-cooling resulted the shortest leaves in both the chipping and twin-scaling methods in the second season only (Fig. 4). However, hot-water treatment resulted the shortest roots per bulblet on the chipping method in the first season only (Fig. 5). In cooling-stored bulbs, number of leaves and length of roots, were declined with hot-water treatment in first season (Figs. 4 and 5).

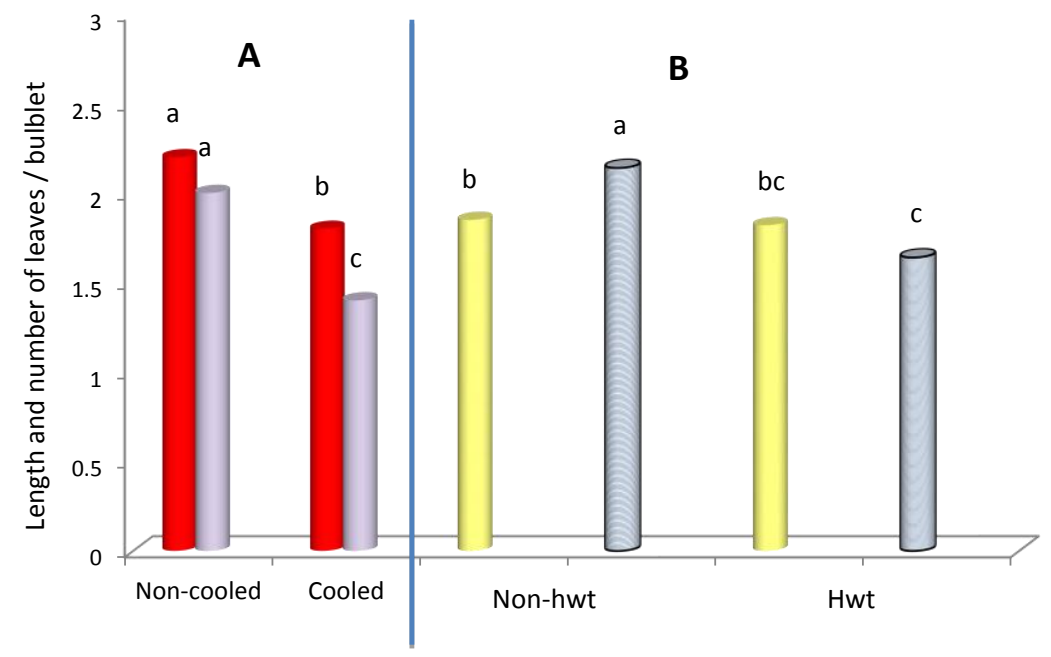

Figure 4. Effect of cutting methods and bulb storage temperature on length of leaves $(\mathrm{cm})$ in the second season (A), and hot-water treatments and bulb storage temperature on number of leaves in the first one (B) (other details are as in Fig. 1)

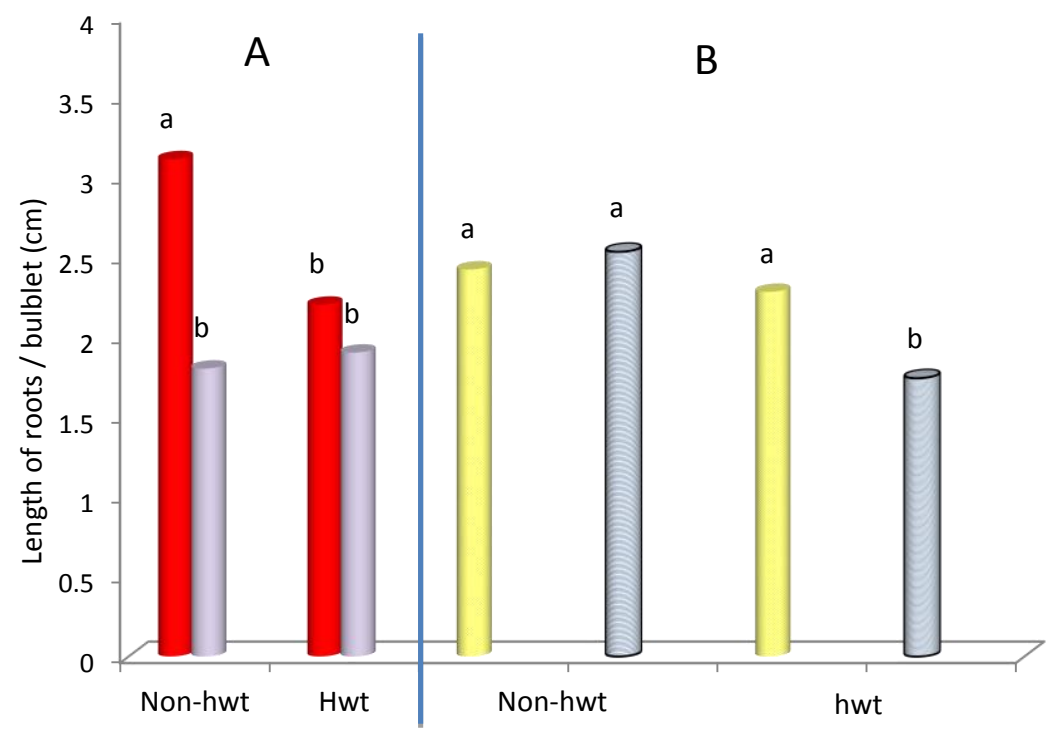

Figure 5. Effect of cutting methods and hot water treatments (A), and hot water treatments and bulb storage temperatures on length of roots/bulblet $(\mathrm{cm})$ in the first season $(B)$ (other details are as in Fig. 1) 


\section{Discussion}

Chipping method consistently affected the bulblet formation and gave greater bulblet weight, circumference and number of bulblets per propagule. The advantage of propagation by the chipping method are simpler and rapid multiplication that produces large quantities of good quality bulb with a relatively short period, but it is less productive (Hanks, 1993). As known, chips had more scales and wider basal plate than twin-scales, suggesting that a higher content of nutrients was stored in the chips. However, the variation in bulblet formation, weight and circumference of bulblet and number and length of leaves and roots observed in Table 1, may be a result of variation in amount of food reserve (Hanks, 1985; Chen and Ziv, 2005; Zahng et al., 2013). The obtained results are similarly to the findings of Roxas et al. (2000) who reported that bulblet formation from cutting mother bulbs of Lycoris species into $1 / 4$ and $1 / 8$ sections (chips) was higher than that from $1 / 16$ sections. Thus, as pointed out by Seyidoglu and Zencirkiran (2008), Fenlon et al. (1990), Kharrazi et al. (2017) and Zhu et al. (2005) in several Amaryllidaceae species, a linear relationship between bulblet weight per chip and initial chip weight, based on parent bulb weight (which would reflect chip weight) and number of chips per bulb (cutting rate). Some species require a cold treatment for subsequent initiation and development of bulblet primordia and for rapid, synchronous growth (Khodorova and Boitel-Conti, 2013). The effect of previous bulb storage temperature on the performance of chips and twin-scales propagation was reported in earlier studies on Narcissus. Rees and Hanks (1984) found that pre-chipping storage temperature $\left(5\right.$ days at $35^{\circ} \mathrm{C}$ ) reduced bulblet formation, whereas pre-cooling ( 5 weeks at $9{ }^{\circ} \mathrm{C}$ ) alone or after a warm storage did not affected bulblets formation. Hanks et al. (1986) showed that pre-twin-scaling storage temperature (0-10 weeks at a range of 5$30{ }^{\circ} \mathrm{C}$ ) produced bulblets in all cases, while the greatest bulblet formation was produced in bulbs stored at 15 and $30^{\circ} \mathrm{C}$ for 6-7 weeks. Chen and $\mathrm{Ziv}$ (2005) reported that, in vitro, the twin-scales isolated from the Narcissus tazetta "Ziva" bulbs after 12 weeks in storage at $30^{\circ} \mathrm{C}$ and a 6 weeks cold treatment at $15^{\circ} \mathrm{C}$ produced high number of uniform adventitious buds and were able to regeneration on the semi-solid medium. They observed also that, higher starch levels were found to correlate to higher regeneration potentials in twin-scales. Our experiments show that, twin-scales required a cold treatment to induce bulblets formation more than those with chips. However, 86 and $100 \%$ (in both seasons, respectively) of chips produced bulblets, while bulblet formation for twin-scales did not reach $100 \%$ in any treatment, but 84.51 and $96.59 \%$ of twin-scales produced bulblets in pre-cooling treatment. Hot-water treatment is the established method for controlling nematodes and bulb scale mite in Narcissus planting stocks (Hanks, 1991, 1993). The effectiveness of hwt may vary depending on pre-hwt storage temperature and date of application. However, pre-hwt storage temperatures around $30{ }^{\circ} \mathrm{C}$ are used for preventing damage, lower temperatures are also effective if used for longer durations (Hanks, 1991). Vreeburg and van der Weijden (1987) stated that bulblet yields was greatest in bulbs given hwt $\left(2 \mathrm{~h}\right.$ at $\left.43.5^{\circ} \mathrm{C}\right)$ with formaldehyde before chipping with 5 days. In the study, bulblet formation was significantly greater due to either hwt or to pre-cooling and hwt interaction in both seasons, while there were insignificant differences in fresh weight and circumference of bulblet. Although, for Horticultural application or production purposes, twin-scaling method is used for propagation because of its potentially greater multiplication rates. 


\section{Conclusion}

The current study showed that in chipping technique the segments produce larger but fewer bulblets per bulb than those produce by twin-scaling and may reach flowering size more quickly. However, hot-water treatment, pre-cooling of bulbs before twinscaling improved bulblet formation and yields. Although relatively labor-intensive, twin-scaling dose have an important role to play in bulking-up schemes, because of its potentially greater multiplication rate. On the other hand, in chipping method, size of parent bulb and number of chips per bulb must be taken into consideration.

\section{REFERENCES}

[1] Bastida, J., Berkov, S., Torras, L., Pigni, N. B., De Andrade, J. P., Martinoz, V., Codina, C., Viladomat, F. (2011): Chemical and Biological Aspects of Amaryllidaceae Alkaloids. - In: Munoz-Torrero, D. (ed.) Recent Advances in Pharmaceutical Sciences. Transworld Research Network, Kerala, pp. 65-100.

[2] Chen, J., Ziv, M. (2005): The effects of storage condition on starch metabolism and regeneration potentials of twin-scales and inflorescence explants of Narcissus tazetta. In-vitro Cell. Dev. Biol. Plant 41: 816-821.

[3] Fenlon, J. S., Jones, S. K., Hanks, G. R., Langton, F. A. (1990): Bulb yields from Narcissus chipping and twin-scaling. - J. Hortic. Sci. 65: 441-450.

[4] Hanks, G. R. (1985): Factors affecting yields of adventitious bulblets during propagation of Narcissus by the twin-scaling technique. - J. Hortic. Sci. 60: 531-543.

[5] Hanks, G. R. (1991): Pre-Warming of Narcissus, prior to Hot-Water Treatment, in Lincolnshire. - Hort. Development Council, Petersfield. HDC Project BOFIS. HRI Project 30284.

[6] Hanks, G. R. (1993): Narcissus. - In: De Hertogh, A. A., Le Nard, M. (eds.) The Physiology of Flowering Bulbs. - Elsevier Sci. Pub., Amsterdam, pp. 463-558.

[7] Hanks, G. R., Rees, A. R. (1978): Factors affecting twin-scale propagation of narcissus. Sci. Hort. 9: 399-411.

[8] Hanks, G. R., Shaik, G., Jones, S. K. (1986): Bulblet production in Narcissus: the effect of temperature and duration of storage on bulb unit development and subsequent propagation by twin-scaling. - Ann. Appl. Biol. 109: 417-425.

[9] Kharrazi, M., Tehranifar, A. Nemati, H., Bagheri, A. (2017): Vegetative propagation of amaryllis (Hippeastrum $\times$ johnsonii) by different cutting methods. - Horticultural Science and Technology 35(3): 373-380.

[10] Khodorova, N. V., Boitel-Conti, M. (2013): The role of temperature in the growth and flowering of geophytes. - Plants 2: 699-711.

[11] Kington, S. (1989): The International Daffodil Checklist. - Royal Horticultural Society, London.

[12] Malik, M., Bach, A. (2017): High-yielding repetitive somatic embryogenesis in cultures of Narcissus L. 'Carlton'. - Acta Sci. Pol. Hortorum Cultus 16(2): 107-112.

[13] Andrade-Rodríguez, M., Guillén-Sanchez, D., Villegas-Torres, O. G., Ayala-Hernández, J. J., López-Martinez,V., Vargas-Araujo, J. (2015): Bulb cutting methods to propagate Hippeastrum hybridum. - Hort. Rev. Chapingo Ser. Hortic. 21(1): 57-69.

[14] Rees, A. R. (1972): The Growth of Bulbs. - Academic Press, London.

[15] Rees, A. R. (1992): Ornamental Bulbs, Corms, and Tubers. - CAB International, Wallingford, UK.

[16] Rees, A. R., Hanks, G. R. (1984): Storage treatments for very early forcing of narcissus. J. Hortic. Sci. 59: 229-239.

[17] Roxas, U. A., Lapichino, G., Zizzo, G. V. (2000): Effect of different bulb sections on Lycoris bulblet multiplication by chipping. - Acta Hortic. 517: 99-106. 
[18] Seyidoglu, N., Zencirkiran, M. (2008): Vegetative propagation of Sternbergia lutea (L) Ker Gawl. ex Sprengel (Winter Daffodil) By chipping techniques. - J. Biol. Sci. 8: 966969.

[19] Snedecor, G. W., Cochran, W. G. (1980): Statistical Methods. $7^{\text {th }}$ Ed. - Iowa State Univ. Press, Ames, Iowa.

[20] Vreeburg, P. J. M., Van der Weijden, G. J. M. (1987): Parteren van narcissen. - Waarom, wanneer en hoe Bloembollencultuur 98(25): 14-15.

[21] Zhang, W., Song, L., da Silva, J. A. T., Sun, H., (2013): Effects of temperature, plant growth regulators and substrates and changes in carbohydrate content during bulblet formation by twin-scale propagation in Hippeastrum vittatum 'Red lion'. - Scientia Horticulturae 160: 230-237.

[22] Zhu, Y., Liu, K. S., Yiu, J. C. (2005): Effects of cutting method on bulb production of Hippeastrum hybridum in Taiwan. - ISHS Acta Horticulture 673: 531-535. 